\title{
Kentsel Açık Mekânlarda Kadınlar: Cinsiyet Rollerinin Kamusal Alanlarda Gözlemlenmesi
}

\author{
Sema MUMCU ${ }^{1}$, Serap YILMAZ², Tuğçe YAZICl ${ }^{3}$
}

öz

Türkiye'de son yıllarda giderek artan kadına yönelik şiddet olayları toplum ve basında önemli bir tartışma konusu olmuştur. Bu konuda ele alınan en önemli sorunlar arasında kadına karşı eşitsizliğin giderilmesi ve sosyal statülerinin iyileştirilmesi yer alır. Ancak tartışmalar genellikle kadını özel alanılarda/aile içinde ele alırken kentsel açık mekânlarda süregiden eşitsizliğe ve karşılaştıkları baskılara yeterince dikkat çekilmemektedir. Bu durum Türkiye'de kadınların kentsel açık mekânlara erişimini ve kullanımını kısıtlamakta ve kadınlar bu alanlarda erkeklerle aynı derecede özgürlüğe sahip olamamaktadırlar. Bu mekanların kadınlar için daha erişilebilir ve kullanılabilir kılınmasına yönelik sorunların tespit edilmesi ve çözümler geliştirmek yalnızca yasalar ve sosyal kuruluşların görevi değildir; peyzaj mimarları da bu konuda önemli sorumluluklar taşırlar. Bu nedenle toplumsal cinsiyet rollerinin ve kentin kamusal hayatı üzerindeki etkilerinin anlaşılması bu meslek disiplini için önemlidir.

Bu çalışma kentsel açık mekânların kullanımında kadınların erkeklere göre sergiledikleri farklılıkları ortaya koymayı ve günümüzdeki yaygın kadın-erkek eşitsizliği tartışmalarına farklı bir açıdan yaklaşmayı amaçlar. Bu nedenle mekânsal kullanımlar ve etkinlik türleri açısından cinsiyet farklılıkları irdelenmiş ve sonuçlar kadınların yaşadığı eşitsizliğin ve karşılaştıkları olumsuz tutumların yansımaları olarak kabul edilmiştir

Araştırmada Trabzon kent merkezinde yer alan yaya alışveriş sokağında davranış gözlemi ve anket çalışması yürütülmüştür. Araştırma sonucunda kadınların açık mekânları kullanırken erkekler kadar özgür hissetmedikleri, alanda erkek kullanıcılara oranla daha az sayıda oldukları, daha az sıklıkta geldikleri ve alana kimlerle geldikleri bakımından daha seçici oldukları tespit edilmiştir.

Anahtar kelimeler: Toplumsal Cinsiyet, Kentsel Açık Mekân, Cinsiyetlendirilmiş Mekân, Kadın

\section{Women in Urban Open Spaces: Observing Gender Roles in Public Spaces}

\begin{abstract}
Increasing violence against women became an important subject of debate in Turkey nowadays. One major problem is how to overcome inequity for women and improve their social status. Approaches have mostly focused on women in the private sphere, domestic life, but inequity and oppresisions that they have to confront in open public spaces are neglected. This situation has made open spaces restricted for access and use for women in Turkey, and they do not have the same amount of freedom as men. It is not only the duty of the law and social organizations but also the duty of landscape architects to find the reasons for these issues and develop solutions to make public spaces more accessible and usable for women and make them feel freer there; landscape architects share important responsibilities. Therefore, it is important for landscape architects to know gender roles and their impact on life in open public spaces.
\end{abstract}

This study aims to reveal the differences that women display in using urban open spaces from men and to approach from a different point of view to the debates about woman-man inequity. Therefore, gender differences in spatial use and activity types were considered and the results were accepted as the reflections of inequity and adverse attitudes that women face.

In this research behavior observation and questionnaire techniques were used in the selected study area which is a pedestrian mall located in Trabzon city centre. The results revealed that women do not feel as free as men, woman users are fewer and visit the area less frequently than men and they are more selective in terms of with whom they are coming with.

Key Words: Gender, Urban Open Space, Gendered Space, Woman

\footnotetext{
${ }^{1}$ Yrd. Doç. Dr., Karadeniz Teknik Üniversitesi, Orman Fakültesi, Peyzaj Mimarlığı Bölümü, semamumcu@ktu.edu.tr,

${ }^{2}$ Yrd. Doç. Dr., Karadeniz Teknik Üniversitesi, Orman Fakültesi, Peyzaj Mimarlığı Bölümü

${ }^{3}$ Karadeniz Teknik Üniversitesi, Fen Bilimleri Enstitüsü

*ilgili yazar / Corresponding author: Sema MUMCU, semamumcu@gmail.com

Gönderim Tarihi: 08.11 .2016

Kabul Tarihi: 20.12 .2016
} 


\section{GíRiş}

Giderek artan kadına yönelik şiddet oranı nedeniyle kadınların sosyal statüsü Türkiye'de tartışılan yaygın konulardan biri haline gelmiştir. Kadına yönelik eşitsizliğin nasıl giderileceği ve sosyal statülerinin nasıl iyileştirileceği başlıca çözümlenmesi gereken sorunlardır. Bu konuya yaklaşımlar, kadının sosyal statüsüne odaklanarak aile içi, özel alanlarda tartışmakta, ancak kadınların kentsel açık mekânlardaki sosyal hayatı ve gerçekleştirdikleri etkinlikler gözden kaçmaktadır.

Toplumsal cinsiyet rollerinin neden olduğu toplumsal baskılar (geleneksel, dini ya da ideolojik) Türkiye'de kadınların açık mekânlara erişimi ve kullanımını kısıtlamakta, bu alanlarda erkeklerle aynı düzeyde özgürlüğe sahip olamamaktadırlar. Day (2000, s. 103-104) kadınların erkeklere göre daha aşağı statüde görülmelerinin kamusal alanları kullanımlarını kısıtlandırdığını açıklar ve kadınların kentsel açık mekânlara ilişkin deneyimlerinin daha iyi anlaşılabilmesi için teorik gelişmelere intiyaç olduğunu belirtir. Başka bir deyişle kadınların açık mekanlarda yaşadığı kısıtlanmanın nedenlerini ortaya koyan ve çözümler öneren bilimsel çalışmaların sayısı artmalıdır. Bu çalışmada kadınların kentsel açık mekânları kullanımında erkeklere göre sergiledikleri farklııklar ortaya koyulmaya çalışıımış; böylelikle kadının Türk toplumundaki yerinin farklı bir açıdan yansıtılması amaçlanmıştır.

\subsection{Toplumsal cinsiyet rolleri ve mekân ilişkisi}

Kadın-erkek ve özel alan-kamusal alan ayrımı literatürde sıklıkla bağlantılı olarak ele alınır ve bu ayırım ya da ikilik ataerkilliği, kadının ikincil konuma itilmesini, kadın-erkek etkinliklerinin ayrılmasını, kadınların kentsel mekânlarda tehlikede oldukları fikrini yansıtırken; kamusal alanları erkek ile (iş yeri), aile içi alanları ise kadın ile (ev işleri) ilişkilendirir (Akın ve Demirel, 2003, s. 73; Demir, 1999, s. 13; Buckingham-Hatfield, 2000 , s. 2; Day, 2000, s. 103, 2001, s. 109; Kansız ve Akın Acuner, 2009, s. 30; Krenichyn, 2004, s. 118; Mehta, 1999, s. 79; Reid, 2008, s. 489-490; Rendell, 1999, s. 101).

Kadınlar ve erkeklerin aynı mekâna ilişkin deneyimleri birbirinden oldukça farklı olabilir (Massey, 1999, s. 129; Sewell, 2003, s. 238). Bu farklılığı açıklamaya çalışan araştırmalar genellikle iki görüş üzerine odaklanırlar. Bu farklılıklar, mekânın fiziksel özelliklerinin ve/ya da kullanıcıların içinde bulundukları toplumun, toplumsal inşalarının sonucudur.

Mekânın fiziksel özelliklerine göre kadın-erkek farklılığını ele alan araştırmalar, kadınların saldırıya uğrama korkusuna odaklanır; taciz ve şiddet korkusu uyandıran açık mekân fiziksel özelliklerini ve kadınların bunun üstesinden gelme stratejilerini açıklamaya çalışır (Blöbaum ve Hunecke, 2005, s. 467-482; Burgess, 1998, s. 126128; Fisher ve Nasar, 1992, s. 35-65; Wesely ve Gaarder, 2004, s. 647-649). Bu gruptaki araştırmalar kadınların saldırıya uğrama korkusunu erkeklere göre daha yoğun hissettiğini vurgular. Açık mekânlarda risk olarak algılanan özellikler; çevrelenme, kapana kısılma (kaçma imkânının olmayışı), yüksek düzeyde görsel korunma (örtülme) düşük düzeyde görsel hâkimiyet (açıklık), çevreden gözetim eksikliği (görsel geçirgenlik), yabancılarla karşılaşma ve özellikle erkeklerin sergilediği tehditkar ve şiddet içeren davranışlar olarak açıklanmıştır. Kadınların kentsel açık mekânlardaki korkularıyla başa çıkma stratejileri ise; herhangi bir tehlike işaretine karşı çevrenin sürekli denetlenmesi, tehlikeli olarak bilinen yerlerden uzak durma; köpek, çocuk, arkadaş, eş ya da akraba ile dışarı çıkma kısaca yalnız çıkmama, yalnızca ana yolları başkaları da varken kullanma, görüş açısının açık olmasından emin olma; yalnızken 
yoğun çalılık ya da ağaçlık alanlardan uzak durma, bu alanları yalnızca gün içinde kullanma, daha erkeksi giyinme ve davranışları sınırlandırma olarak tanımlanmıştır (Burgess, 1998, s. 126-128; Koskela, 1999, s. 121; Starkweather, 2007, s. 357-359; Wesely ve Gaarder, 2004, s. 649,656).

Farklılıkları toplumsal inşaların sonucu olarak gören araştırmalar ise genellikle kültürel ya da sosyal faktörlerin cinsiyetlendirilmiş mekânların üretimine etkisine işaret eder. Bu araştırmalar kadına toplum tarafından yüklenen cinsiyet rollerini anne, ev hanımı, alışverişçi, zayıf, savunmasız, kaotik, hassas, korkak ve pasif olarak sıralandırırken; erkeğe yüklenenleri aile reisi, çalışan, güçlü, rekabetçi, baskın, mantıklı, korkusuz ve aktif olarak sıralar. Bunlar doğrultusunda bu rollerin kentsel kamusal alana nasıl yansıdığı özellikle kadınlar ve erkeklerin kamusal alanlara erişiminde yaşanan eşitsizlik; kadının yerinin evin özel alanı ya da alışveriş merkezleri olması, erkeğin alanın ise iş yeri ya da şehir merkezi ve açık mekânlar olmasıyla ilişkili olarak açıklanmıştır (Ardener, 1999, s. 115-116; Buckingham-Hatfield, 2000, s. 5-6; Günindi Ersöz, 2015, s. 80; Massey, 1999, s. 129-130; Sewell, 2003, s. 239). Kadınla ilişkilendirilen cinsiyet rolleri, üzerlerinde yüksek düzeyde bir sosyal baskı oluşturmakta bunun sonucunda da kadınların kentsel kamusal alanlara erşimi kısıtlanmaktadır.

Araştırmacılar cinsiyet rollerinin inşasını kadınların kentsel kamusal alanlardan uzaklaşmasının nedeni olarak görür ve kadınların açık mekândaki rekreasyon etkinliklerine katılımında ana engel olarak tanımlar (Wesely ve Gaarder, 2004, s. 646). Kadınların erkeklerle paylaştıkları mekânlarda güçsüz bir konumda kalmaktansa erkeklerle eşit kontrol düzeyine sahip olmaları gerektiği belirtilir (Sewell, 2003, s. 253). Tercih edilen kentsel kamusal alanlar arkadaşlar, aile ve yabancılarla etkileşimi teşvik eder (Day, 2000, s. 110). Bu tür yerler kadınların psikolojik intiyaçları da dahil olmak üzere ihtiyaçlarını doğru bir şekilde öngörüp karşılarlar. Kadınların refahı ve sosyal süreçlerine önemli olan bu katkılarından dolayı cinsiyetlendirilmiş kentsel açık mekânlar incelenerek insan yapımı çevrenin cinsiyet rollerinin inşası ve sosyal değişim süreçlerindeki rolü anlaşılabilir. Bunlar doğrultusunda da cinsiyetlendirilmiş kamusal alanların oluşumunu ve kadınların erişimindeki eşitsizliği gidermek için başarılı planlama ve tasarım kararları alınabilir.

\subsection{Türkiye'de toplumsal cinsiyet ve kentsel açık mekânlarda kadınlar}

Batı'daki çalışmalar kadın-erkek eşitsizliğinin nedeni olarak cinsiyet rollerini (kadın: anne, ev kadını, zayıf; erkek: baba, evin reisi, güçlü) gösterirken Türkiye'de kadınlar üzerinde baskı oluşturan faktörler daha çeşitli ve yoğundur. Batı ülkelerindekilere benzer şekilde Türkiye'de de kadınlar ataerkil cinsiyet rolleri ile kısıtlanmakta, aynı zamanda dini ve ideolojik kaynaklı baskılar da onları kuşatmaktadır. Bu baskıların kadınların kentteki kamusal hayata katılmalarındaki yansıması olumsuz olmaktadır. Bunun sonucu olarak Türk kadının toplumsal görünümü ekonomik ve sosyal alanlardan dışlanmış, erkeğe göre daha az eğitimli ve kamusal alanda daha az görünür, daha yoksul ve daha çok şiddete maruz kaldığı şeklinde özetlenebilir. Eşitsizliğe ilişkin sorunlar açıklanırken genellikle eğitim, karar aşamaları, iş piyasası, politika vb. gibi konulara odaklanılmaktadır. Kadının kentsel açık mekânlardaki görünürlüğü ve kadınerkek eşitliğine ilişkin çalışmalar yeterli düzeyde değildir. Kadınların kentsel kamusal alanlara erişimini kısıtlayan herhangi bir yasal düzenleme olmasa da diğer kamusal alanlarda olduğu gibi kentsel açık mekânlarda da kadınlar erkeklerle aynı özgürlüğe sahip değildir. Buna ilişkin nedenler şöyle sıralanabilir:

- Kadınlar erkeklere göre daha yoğun olarak saldırıya uğrama korkusunu hissederler (Kansız ve Akın Acuner, 2009, s. 67; Koskela, 1999, s. 111; Fisher ve Nasar, 1992, s. 51) 
- Kadınlar (geleneksel, dini, ideolojik) cinsiyet rollerinden kaynaklı baskıdan dolayı sosyal hayatta davranışlarına dikkat etmekle yükümlüdür (Demir, 1999, s. 12; Ereş, 2006, s. 47-49; Gökarıksel ve Secor, 2010, s. 131-145; Kansız ve Akın Acuner, 2009, s. 86; KSGM, 2008a, s. 27; KSGM, 2008b, s. 9; Üstün, 2009, s. 362).

- Kadınlar ev işleri ve çocuk bakımından sorumlu olduklarından (KSGM, 2008b, s. 36; KSGM, 2012, s. 26; Yılmaz, 2006, s. 102) genellikle dışarı çıkacak yeterli zamanları kalmamaktadır (Day, 2000, s. 107; Kansız ve Akın Acuner, 2009, s. 79; Yılmaz, 2006, s. 100).

- Kadınlar kendileri için harcayabilecekleri yeteri kadar maddi imkânlara sahip değildir ve ekonomik olarak eşleri ya da ailelerine bağımlıdırlar (Akın ve Demirel, 2003, s. 73; Day, 2000, s. 107; Ereş, 2006, s. 47-49; Kansız ve Akın Acuner, 2009, s. 86; KSGM, 2008b, s. 35,44; Üstün, 2009, s. 387; Yılmaz, 2006, s. 100).

Tüm bu faktörlerin yansıması kentsel açık mekânlarda kolaylıkla izlenebilir. Kadınlar ve kız çocukları kentteki kültürel ve rekreasyonel imkânlardan en az faydalanan kullanıcı grubudur (Kansız ve Akın Acuner, 2009, s. 29).

Bu çalışmada kentsel kamusal alanların kadınların tahammül etmek zorunda kaldığı baskı ve eşitsizliğin en iyi gözlemlenebileceği yerler olduğunu kabul edilir. Kullanıcı cinsiyetlerinin oranları arasındaki farklılıklar ve gerçekleştirilen etkinlikler, bunların mekân içindeki dağılımları eşitsizliğin mekânsal röntgeni olacaktır. Çalışmanın araştırmacıları peyzaj mimarları olduklarından ve doğrudan sosyal bilimler alanından olmadıklarından araştırma konusuna yaklaşımın açıklanması gerekli görülmüştür. Toplumun tüm kesimleri için eşit erişilebilirlikte açık kamusal alanların tasarımından peyzaj mimarları sorumludur. Günümüzde karşılaşılan eksikliklerin çözümlenmesinde yalnızca kanunlar ya da sosyal organizasyonlar sorumlu değildir; kadınlar için kentsel kamusal alanların daha erişilebilir ve kullanışı olması, kendilerini daha özgür hissetmelerinin sağlanması, buna ilişkin cevapların bulunması ve çözüm üretilmesi aynı zamanda peyzaj mimarlığı meslek disiplininin de görev alanına girer. Peyzaj mimarları; sosyologlar, hukukçular ve sivil toplum kuruluşları gibi diğerleri ile birlikte sorumlulukları paylaşmalıdır. Bu nedenle cinsiyet rollerinin ve bunların kentsel kamusal alanların kullanımı üzerindeki etkisinin anlaşıması önemli bir gerekliliktir.

Hükümetin "Toplumsal Cinsiyet Eşitliği Ulusal Eylem Planı 2008-2013" raporunda kadının günümüzdeki statüsü; eğitim, ekonomi, güç ve karar verme mekanizmaları, yoksulluk, sağlık, medya, çevre, insan hakları ve şiddet başlıkları altında tartışılmıştır. Kadın ve çevre başlığı (KSGM, 2008b, s. 63,67) altındaki yaklaşım oldukça yetersizdir; çevre sadece fiziksel-ekolojik bağlamda ele alınmış; sosyal, kültürel ve algısal boyutları tamamen göz ardı edilmiştir. Raporda odaklanılan tek konu çevresel kirlilik iken cinsiyet rollerinin kadınların kentsel açık mekânları kullanımına nasıl yansıdığı ya da bu alanlarda nasıl hissettikleri, bu alanları nasıl imgeledikleri ya da kentsel çevrelerdeki görünürlükleri gibi konular dile getirilmemiştir. Kısacası sosyal çevre boyutu tamamen göz ardı edilmiştir. Ayrıca aynı bakanlık tarafından yürütülen "Kadın Dostu Kentler" (BMOP, 2010) adlı çalışmadan bu raporda bahsedilmemiştir. Bu durum hükümetin bölümleri arasındaki koordinasyon eksikliğini göstermektedir.

Türkiye'de kadınların statüsü için olumlu gelişmeler de gözlenmektedir. Kent hizmetlerinden yararlanma düzeylerini ve kadınların kentlerdeki görünürlüğünü artırmak üzere çeşitli çalışmalar gerçekleştirilmiş, "Kadınların ve Kız Çocuklarının İnsan Haklarının Korunması ve Geliştirilmesi Ortak Programı (UNJP/BMOP)-Kadın Dostu Kentler" projesi kapsamında altı kenti içeren stratejik planlar ortaya koyulmuştur. Yürütülen çalışmalarla kadınların kentsel yaşamın unutulan değil, temel ve belirleyici 
bireyleri olduğu ortaya vurgulanmıştır (BMOP, 2006, s. 4). Bu program dahilinde kentlerin fiziksel özelliklerinin nasıl iyileştirileceğine dair somut sonuçlar ortaya koyan çalışmalar yürütülmüştür. Canlı, uzun süre faal kalabilen ve sürdürülebilir kentsel açık mekânların tasarımı, mekânlar arasındaki hareketliliğin artırılması, mekânların algılanabilir ve okunabilir düzeni, görüş alanını kısıtlamayacak peyzaj tasarımları, iyi aydınlatma, sokaklar ve diğer alanlarda net ve kolay anlaşılabilir işaretler, gözetimin artırılması vb. gibi önlemler fiziksel çevrenin kalitesinin artırılması üzere tavsiye edilmiştir (BMOP, 2010, s. 49).

Kentsel kamusal alanlar ve cinsiyet ilişkisine dair yürütülen bazı araştırmalar da mevcuttur. Türkiye'de açık mekân-cinsiyet ilişkisine odaklanan bir araştırmada Trabzon kentinde kadınların sosyal baskılar ve ekonomik durumları nedeniyle kamusal alanlara erişimlerinin sınırlı olduğu tespit edilmiştir. Kadınların öncelikle güvenlik sorununu dile getirdiği ve bazı fiziksel özelliklerin kadınlarda korku uyandırdığı ortaya koyulmuştur (Yılmaz, 2006, s. 107-108). Aynı kentte yürütülen kadınların sosyal statüsüne ilişkin başka bir çalışmada da kadınların evleri dışındaki mekânları kullanımının ve sosyal yaşamı paylaşmaya ilişkin fırsatların toplumsal inşalarla kısıtlandığını saptanmıştır (Üstün, 2009, s. 386). Kentleşme ile sağlanan yeni fırsatlar olsa da bunlar kadınlar için kullanılabilir değildir. Bu çalışma ayrıca kadınların kentsel kamusal alanlara erişimlerini kolaylaştırmak için erkeksi giyinme ya da davranışlar sergileme gibi önlemler aldığını ortaya koymuştur. Bir başka bulgu da kafeler, parklar, deniz kıyısı gibi alanların yalnızca gün içinde kadınlar için kullanılabilir olduğunu gösterir. Havanın kararmasıyla bu alanlar kadınlar için uygun olmayan yerlere dönüşmektedir. Kadınların ev dışında olmak için belirttikleri en yaygın neden alışveriştir. Bu nedenle kadınların en sık kullandığı alanlar alışveriş merkezleridir (Üstün, 2009, s. 384-387). İnce Güney (2014, s. 157) Balıkesir kent merkezinde yaptığı yayalara ilişkin davranış gözlemlerinde erkek kullanıcıların ağırlıkta olduğunu, tespit edilen oranın İstanbul kent merkezindeki çeşitli noktalarda tespit edilen erkek yoğunluğundan daha fazla olduğunu ortaya koymuştur. Görsel analizlerle, yaya hareketlerinin cinsiyetlere göre ilişkisinin kurgulandığı çalışmada kadınların görsel bütünlüğün sağlandığı özellikle mağazaların olduğu sokakları daha yoğun kullandığı ve görsel özellikler bağlamında kullanımın cinsiyetlere göre farklılaştığı tespit edilmiştir (İnce Güney, 2014, s. 166-168). Tiftik ve Turan (2015, s. 243-252) kentsel mekânlarda kadın kavramını güvenlik ve saldırıya uğrama korkusu bakımından ele almışlar, toplu konut alanlarında daha güvenli mekânların tasarım kriterlerini irdelemişlerdir. Demirbaş (2012, s. 2) gecekondu mahallesindeki kadınlara odaklandığı çalışmasında ataerkil roller bağlamında kadınların mekân algısı ve kullanımını irdelemiştir. Çalışma kapsamında kadınlarla yapılan görüşmeler sonucunda kadınlar yanlarında bir erkek olduğunda, belirli bir yaşın üzerinde olduklarında ve yanlarında çocukları yoksa kentte daha az sorun yaşadıkları tespit edilmiştir. Bununla beraber ancak çocuk sayesinde kent merkezine çıkabildiğini belirten kadınlar da olmuştur. Bir kadının kentle ilişkisinde "can yeleği" olarak adlandırdığı kişiler [çocuk, akrabalar, komşu kadınlar, eş] söz konusudur (Demirbaş, 2012, s. 86). Çalışmada ayrıca gelir düzeyinin de kent merkeziyle kurulan ilişkiyi belirleyen bir özellik olduğu, paralarını belirli ölçülerde daha rahat kontrol edebilen kadınların kent merkezine daha sık çıktıkları belirlenmiştir (Demirbaş, 2012, s. 88). Gebze'de yürütülen bir başka araştırma ise kent merkezi ve çarşı gibi alanlarda erkek kullanıcıların oranlarının kadınlara göre oldukça yüksekken, alışveriş merkezi ya da konut sokaklarının olduğu alanlarda yakın oranlarda olduğunu; erkeklerin kadınlara oranla kamusal mekânları daha sık ziyaret ettiğini ve kadınların sokaktayken yanlarında birisinin varlığıyla kendilerini daha iyi hissettiğini tespit etmiştir (Bayazitoğu ve Ayyıldız Potur, 2013, s. 545)

Ancak hala "Kadınlar evlerinin dışında, kentte neler yaparlar? Kentsel açık mekânlar kadınları özgürleştirir mi? Kadınlar ve erkeklerin açık kamusal alanları kullanımındaki 
farklılıklar nelerdir?" gibi sorular yanıtlanmamıştır. Çınar (2005, s. 41) cinsiyet kimliklerinin yalnızca kadınların kamusal alanda nası göründükleri ile yansıtılmadığını aynı zamanda dahil oldukları etkinlikler ve bu alanlarda neler yaptıklarının da cinsiyet rollerinin yansıması olduğunu belirtir.

Bu çalışmada kentsel açık mekânları kadınların nasıl kullandığı ve katıldıkları etkinliklerin belirlenmesi ile kadınların cinsiyet rollerinin ve bunların mekân kullanımına etkilerinin saptanması amaçlanmıştır. Bu rollerin mekânın kullanımına nasıl yansıdığının ortaya koyulması ile kadınlar için daha demokratik açık mekânların nasıl tasarlanabileceğine dair tartışmalar yapmak mümkün olacaktır. Çalışıma kapsamında yürütülecek analizlerle Türk toplumundaki cinsiyet rollerinin inşası ve kadın-erkek eşitsizliği sorununa bağlı olarak kadın kullanıcıların erkek kullanıcılara oranla kentsel açık mekânlara daha kısıtlı bir erişime sahip olduğunun ortaya koyulması beklenilmektedir.

\section{METODOLOJi}

$\mathrm{Bu}$ çalışmada başlıca iki tekniği bir araya getiren bir çalışma yürütülmüştür. İlk aşamada yapılandırılmış davranış gözlemi yürütülmüş ve gözlem ile elde edilemeyecek kullanıcı değerlendirmelerinin saptanmasına yönelik olarak anket gerçekleştirilmiştir. İkinci aşama davranış gözlemi ve anket verilerinin bir arada değerlendirilmesini içerir.

\section{1. Çalışma Alanı}

Araştırma "Kadın Dostu Kentler" projesinin yürütüldüğü altı kentten biri olan Trabzon'da yürütülmüştür. BMOP $(2010$, s. 151) raporuna göre kent popülasyonunun \%49,4'ü erkek, \%50,6'sı kadındır. Popülasyonun \%52,2'si kent merkezinde yaşamaktadır. Erkeklerin okuma yazma oranı $\% 97,5$, kadınlarda $\% 83,8$ 'dir. Çalışan erkek oranı $\% 74,5$ iken kadın oranı ancak \%48,2 düzeyindedir. Eğitim ve iş gücüne katılım oranları arasındaki fark kadın ve erkek statüleri arasındaki eşitsizliğin göstergesidir.

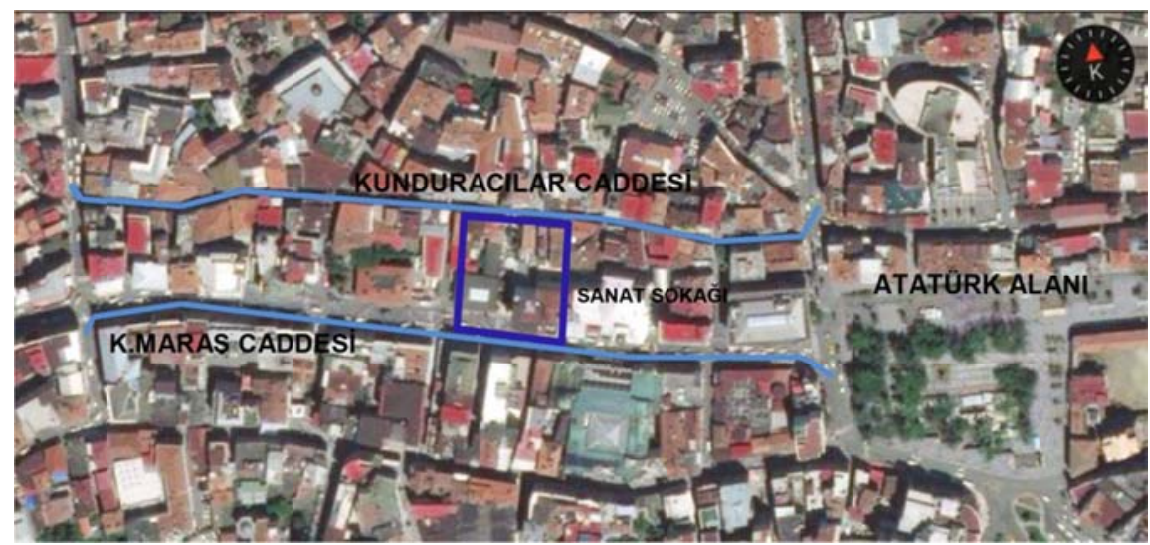

Şekil 1. Çalışma alanı olarak seçilen Sanat Sokağı'nın kent merkezindeki konumu

Kent merkezinde yer alan ve kent hayatının en canlı, başlıca mekânları olan yaya alışveriş sokaklarından Kunduracılar Caddesi-Sanat Sokağı çalışma alanı olarak seçilmiştir (Şekil 1). Kunduracılar Caddesi uzun yıllardır yayalaştırılmış alışveriş sokağı olarak kentin önemli ve yoğun bir bileşenidir. Kesişme noktası niteliğindeki alan yoğun kullanıma sahiptir. Mevsimsel mısır, kestane ya da simit gibi sokak satıcılarının sürekli olarak konumlanması, oturmaya yönelik kent mobilyaları içermesi, bitkisel elemanlar ve örtü elamanları içermesi, çiçekçi, yöresel market gibi çeşitli mağazaların dışa açılımı, 
çay ocağı ve buna ilişkin oturma birimlerinin olması sokağı canlı kılan ve sürekli kullanılan bir alan yapmaktadır (Şekil 2).
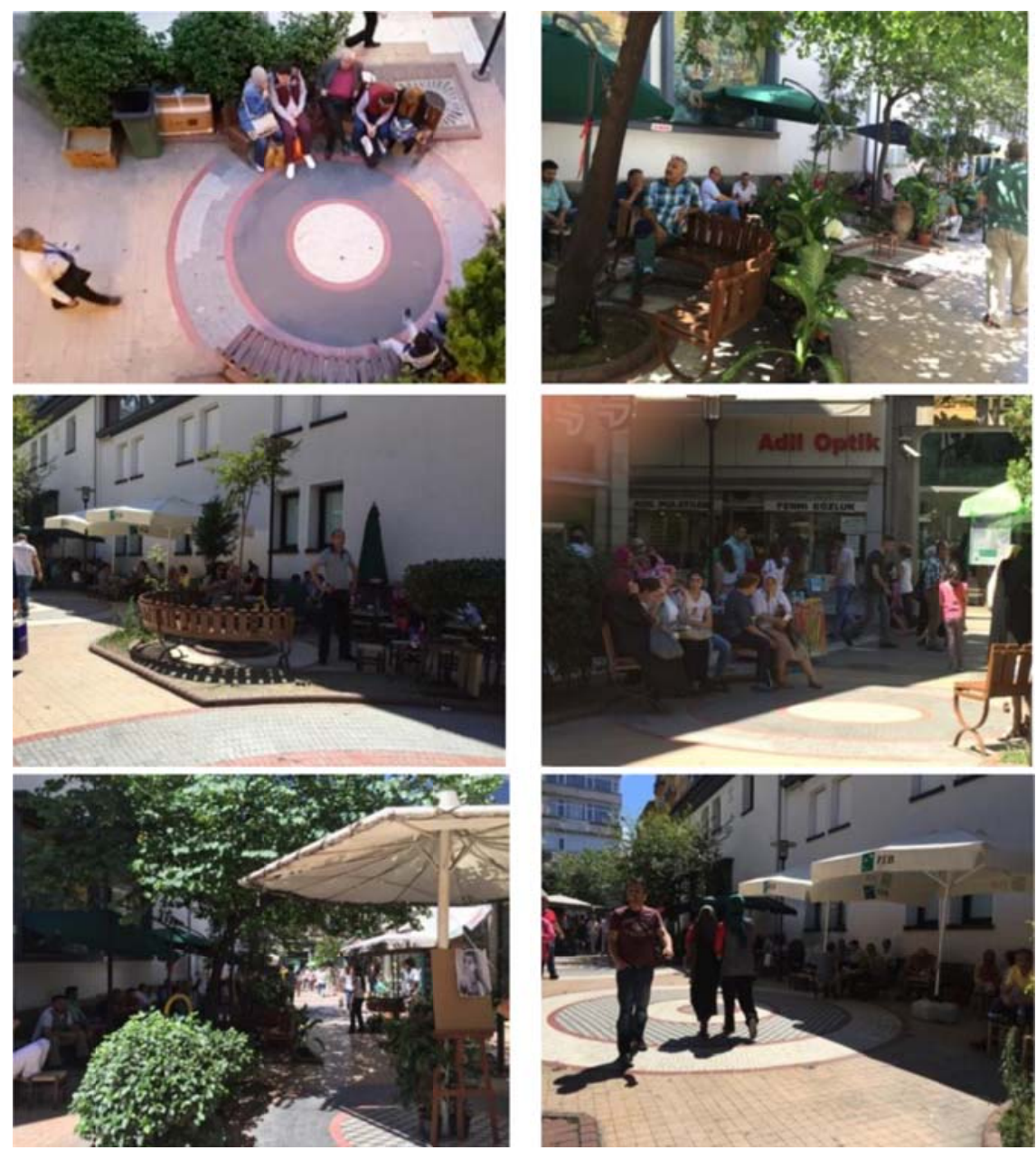

\subsection{Verilerin toplanması}

Şekil 2. Alan içinden görünümler

\subsubsection{Davranış gözlemi}

Çalışma alanında yapılandırılmış davranış gözlemi yürütülmüştür. Sokak hafta içi 3 gün ve hafta sonu 2 gün gözlemlenmiştir. 30 dakikalık peryotlarla, toplamda 19 gözlem seansı ile, gün içi yoğunluğun yüksek olduğu öğleden sonra saatlerinde ve hava koşullarının açık mekânda durmaya uygun olduğu zamanlarda, Mayıs ayı içinde alanda oturmakta ve ayakta durmakta olan bütün kullanıcılar hazırlanan tablolara kaydedilmiştir. Her kullanıcının cinsiyeti, yaş aralığı (çocuk, genç yetişkin, yetişkin, yaşlı), yapmakta olduğu etkinlik, kiminle geldiği (yalnız, çift, hemcinsleriyle, karma grup) konumu (bank, ayakta, çay ocağı) şeklinde tabloya veri olarak aktarımıştır. Bu verilerle; konumlarda cinsiyetler bakımından homojen dağılımların olup olmadığı, yani kadınlar ve erkeklerin mekânı kullanma bakımından eşit özgürlüğe sahip olup olmadığı, sergilenen etkinlikler bakımından cinsiyetlerin ortaya koyduğu farklılıklar, alana kiminle geldiklerine bağlı olarak sergiledikleri eğilimler gibi sonuçların tespiti ve cinsiyet rolleri ile ilişkisinin irdedelenmesi amaçlanmıştır. Bu verilerin SPSS yazılımıyla istatistiki olarak dağılımları incelenmiştir. 


\subsubsection{Anket}

Davranış gözlemi ile elde edilen bulgular kadın-erkek kullanıcıların mekânı nasıl deneyimlediklerini, kadınların cinsiyet rollerine bağlı toplumsal baskı hissedip hissetmediklerini tek başına açıklamakta yeterli değildir. Çalışma toplumsal cinsiyet rolleri ile kentsel açık mekânların kullanımı arasında bağ kurmayı amaçladığından buna ilişkin verilerin toplanabilmesi amacıyla anket çalışması da yürütülmüştür. Literatür taramasına bağlı olarak özgürlük, güvenlik ve rahatılk kavramları göz önünde bulundurulmuş, toplumsal cinsiyet rolleri nedeniyle kadınlar ve erkeklerin bu özellikler bakımından mekânları farklı değerlendireceği varsayılmıştır. Bu doğrultuda Likert Tutum Ölçeği kulllanılmış, bu özelliklere yönelik "kendimi burada güvende hissediyorum", "kendimi burada özgür hissediyorum", "burada istediğim gibi davranabiliyorum", "kendimi burada rahat hissediyorum", "karşı cinsin varlığından rahatsız olmuyorum" gibi değerlendirme cümlelerine "kesinlikle katılıyorum", "katılıorum", "fikrim yok", "katılmıyorum", "kesinlikle katılmıyorum" ifadelerinden biriyle yanıt vermeleri istenmiştir. Olumsuzdan olumluya doğru 1'den 5'e kadar ölçeklendirilen yanıtlar tüm kullanıcılar için toplanmış, cinsiyetler bakımından ortalama değerler elde edilmiş ve kadın-erkek kıyaslamaları yapılabilmiştir. Ayrıca ankette deneklerden sosyodemografik veriler ve konuma gelme, orayı tercih etme nedenleri gibi mekâna ilişkin veriler de toplanmıştır.

\section{BULGULAR}

\subsection{Davranış gözlemine ilişkin bulgular}

Çalışma alanında oturmakta ya da ayakta durmakta olan toplam 629 kullanıcı gözlemlenmiştir. Bunların \%29,9'u (188 kişi) kadın kullanıcılar, \%70,1'i (441 kişi) erkek kullanıcılardır $\left(x^{2}=101,763,1 \mathrm{df}, p<0.00\right)$. Sonuç kadınlar ve erkeklerin bu açık mekâna erişimindeki eşitsizliği yansıtmakta, alanda erkek kullanıcıların baskınlığını ortaya koymaktadır. Kullanıcıların alana kimlerle geldiğinin cinsiyet rolleri ile ilişkili olarak değişeceği varsayılmıştır; daha önceki çalışmalar kadınların açık mekânları kimlerle beraber ziyaret ettikleri konusunda erkeklerden farklı eğilimler ortaya koyduğunu vurgular. Benzer durumun bu alanda da geçerli olup olmadığı sorgulanmıştır.

Çizelge 1. Davranış Gözlemi İle Saptanan Kullanıcıların Cinsiyetlerine Göre Gruplar İçindeki Dağılımları

\begin{tabular}{|c|c|c|c|c|c|c|}
\hline & \multicolumn{5}{|c|}{ LaginImiari } \\
\hline & & \multicolumn{5}{|c|}{ Kullanıcı grupları } \\
\hline & & Yalnız & Çift & $\begin{array}{l}\text { Hemcins } \\
\text { leri ile }\end{array}$ & Karma & Toplam \\
\hline \multirow[t]{4}{*}{ Kadın } & sayı & 42 & 13 & 86 & 47 & 188 \\
\hline & $\begin{array}{l}\text { \% tüm kadınlar } \\
\text { içinde }\end{array}$ & $22,3 \%$ & $6,9 \%$ & $45,7 \%$ & $25,0 \%$ & $100,0 \%$ \\
\hline & $\begin{array}{l}\% \text { her bir grup } \\
\text { icinde }\end{array}$ & $32,6 \%$ & $50,0 \%$ & $22,9 \%$ & $47,5 \%$ & $29,9 \%$ \\
\hline & $\%$ toplam içinde & $6,7 \%$ & $2,1 \%$ & $13,7 \%$ & $7,5 \%$ & $29,9 \%$ \\
\hline \multirow[t]{4}{*}{ Erkek } & sayı & 87 & 13 & 289 & 52 & 441 \\
\hline & $\begin{array}{l}\text { \% tüm erkekler } \\
\text { içinde }\end{array}$ & $19,7 \%$ & $2,9 \%$ & $65,5 \%$ & $11,8 \%$ & $100,0 \%$ \\
\hline & $\begin{array}{l}\% \text { her bir grup } \\
\text { içinde }\end{array}$ & $67,4 \%$ & $50,0 \%$ & $77,1 \%$ & $52,5 \%$ & $70,1 \%$ \\
\hline & $\%$ toplam içinde & $13,8 \%$ & $2,1 \%$ & $45,9 \%$ & $8,3 \%$ & $70,1 \%$ \\
\hline \multirow[t]{2}{*}{ Toplam } & sayı & 129 & 26 & 375 & 99 & 629 \\
\hline & $\%$ & $100,0 \%$ & $100,0 \%$ & $100,0 \%$ & $100,0 \%$ & $100,0 \%$ \\
\hline
\end{tabular}

Yapılan analizler kadınların ağırlıklı olarak hemcinsleri $(\% 45,7)$ ve karma gruplar (\%25) içinde yani başkaları ile beraber alana gelme eğilimi sergilediklerini, erkeklerin ise 
ağırlıklı olarak hemcinsleri ile beraber alana geldiklerini $(\% 65,5)$ daha sonra yalnız gelme eğilimin ağır bastığını $(\% 19,7)$ ortaya koymuştur (Çizelge 1). İstatistiki analizlerin önem düzeyi sergilemesi $\left(x^{2}=28,725,3 \mathrm{df}, p<0.00\right)$ cinsiyetlerin kullanıcıların alana kimlerle gelme eğilimi sergilediği üzerinde etkili olduğunu gösterir. Alanda yalnız olarak gözlemlenen 129 kişinin \%67,4'ü erkek, \%32,6’sı kadın kullanıcılardır.

Çizelge 2. Kullanıcıların Cinsiyetlerine Göre Konumlar İçindeki Dağılımları

\begin{tabular}{|l|l|l|l|l|l|}
\cline { 3 - 6 } \multicolumn{2}{c|}{} & \multicolumn{4}{l|}{ Kullanıcı konumları } \\
\cline { 3 - 6 } \multicolumn{2}{c|}{} & Bank & $\begin{array}{l}\text { Ayak } \\
\text { üstü }\end{array}$ & $\begin{array}{l}\text { Çay } \\
\text { Ocağı }\end{array}$ & Toplam \\
\hline \multirow{2}{*}{ Kadın } & Sayı & 65 & 18 & 105 & 188 \\
\cline { 2 - 6 } & $\%$ & $58,0 \%$ & $41,9 \%$ & $22,2 \%$ & $29,9 \%$ \\
\hline \multirow{2}{*}{ Erkek } & Sayı & 47 & 25 & 369 & 441 \\
\cline { 2 - 6 } & $\%$ & $42,0 \%$ & $58,1 \%$ & $77,8 \%$ & $70,1 \%$ \\
\hline \multirow{2}{*}{ Toplam } & Sayı & 112 & 43 & 474 & 629 \\
\cline { 2 - 6 } & $\begin{array}{l}\% \text { tüm kullanıcılar } \\
\text { içinde }\end{array}$ & $17,8 \%$ & $6,8 \%$ & $75,4 \%$ & $100,0 \%$ \\
\hline
\end{tabular}

Cinsiyet rollerinin mekan kullanımı için de yönlendirici olacağı, kadın ve erkek kullanıcıların alan içinde homojen bir dağılım sergilemeyeceği beklenmiştir. Bu doğrultuda gerçekleştirilen istatistiki analizler (Çizelge 2) tüm kullanıcılar bağlamında alanda en çok kullanılan yerlerin çay ocağına ait sokaktaki oturma yerleri olduğunu $(\% 75,4)$ daha sonra belediyeye ait bankların ağılıkta olduğunu $(\% 17,8)$ ortaya koymuştur. Bu dağılım cinsiyetlere göre analiz edildiğinde \%77,8 ile erkeklerin çay ocağına ait oturma yerlerinde önemli bir farkla ağırlık sergiledikleri, bu konumların erkeklere ait cinsiyetlendirilmiş mekânlara dönüştüğü söylenebilir. Kadınların oran olarak erkekleri geçtiği tek konum oturma banklarıdır, bu konumdaki kullanıcıların \%58'inin kadınlar olduğu tespit edilmiştir. Bu durum çay ocaklarının erkeklere ait mekânlar olarak algılanması, kadınların ekonomik olarak daha kısıtlı hissetmesi ve bankların kadınlar tarafından taburelere göre daha konforlu algılanmasının sonucu olabilir. Cinsiyetlerin konumlara göre dağılımının istatistiki önem düzeyi ortaya koyması $\left(x^{2}=58,824,2 \mathrm{df}, p<0.00\right)$ cinsiyetlerin alan içindeki hangi mekânsal özelliklerin kullanımında tercihi etkilediğini ortaya koymuştur. Daha derinlemesine yapılan analizlerle de konumlardaki kullanıcı grupları özellikle kadın kullanıcılar açısından irdelenmiştir. Kadın kullanıcıların bankları ağırıklı olarak hemcinslerinden oluşan gruplarla ya da yalnızken kullandıkları, çay ocaklarında ise ağılıklı olarak hemcinslerinden oluşan ya da karma gruplar içinde bulundukları gözlemlenmiştir.

Kullanıcıların davranışsal eğilimleri incelendiğinde oturma ya da ayakta durma gibi sabit etkinlikler ile beraberinde gerçekleşen 20 etkinlik türü gözlemlenmiştir. Ağırlıklı olarak alanda çay-sigara eşliğinde sohbet etme, sohbet etme, çay içme, etrafı izleme, alandaki satıcılardan bir şeyler alıp yeme etkinlikleri gerçekleşmiştir. Gözlemlenen 20 etkinlikten 16'sı kadınlar tarafından sergilenmişken, erkekler 15 etkinliği sergilemiştir. Çeşitlilik olarak ele alındığında kadın ve erkeklerin davranışsal olarak farklılık sergilemediği ancak içerik olarak ele alındığında bazı davranışların kadınlar tarafından sergilenmezken (gazete okumak, alandaki seyyar piyangoculardan şans oyunları oynamak ya da kupon doldurmak, uyumak, tespih çekmek gibi) bazılarının da erkekler tarafından sergilenmediği (fotoğraf çekilmek-öz çekim, çocuk bakımı ya da çocukla ilgilenme, alışveriş gibi) gözlemlenmiştir. Ancak gözlem süresinin kısıtııı̆̆ ve alanın tek olması bu davranışların kadınlar ya da erkekler tarafından hiçbir zaman sergilenmediği genellemesini yapmaya elverişli değildir. Yinede istatistiki analizlerin önem düzeyi sergilemesi $\left(x^{2}=60,759,19 \mathrm{df}, p<0.00\right)$ cinsiyetlerin yapılan etkinliklerin değişiminde etkili olduğunu gösterir. 
Kullanıcıların yaş gruplarına ilişkin verilerin analizi kadın ve erkek kullanıcıların benzer dağılımlar sergilediğini ortaya koymuştur. Alan ağılıklı olarak yetişkinler tarafından kullanılırken, bunu genç-yetişkinler ve yaşlılar izlemiştir. Kadınlar ve erkekler olarak ele alındığında da benzer sıralama ile karşılaşılmıştır.

\subsection{Ankete ilişkin Bulgular}

Anket çalışmasıyla mekânın deneyimlenmesinde kadın ve erkeklerin rahatlık, özgürlük, güven gibi duygular bakımından farklılıklarının olup olmadığı incelenmiştir. $\mathrm{Bu}$ doğrultuda alanda 51 kullanıcı ile anket çalışması yürütülmüştür. Anket yapılan kullanıcılara ilişkin sosyo-demografik veriler alan kullanıcılarının çeşitliliğini yansıtır (Çizelge 3).

Alana gelme sıklıkları olarak veriler ele alındığında kadınlar ve erkeklerin farklııklar sergilediği saptanmıştır (Çizelge 4). Alana her gün geldiğini belirten kadın kullanıcı olmamışken erkeklerde bu oran \%29,2 olmuştur. Kadınlar ağılıklı olarak haftada birkaç kez ve haftada bir gelme eğilimi sergilemişken, erkekler haftada bir, haftada birkaç kez ve her gün geldiklerini ağırlıklı olarak belirtmişlerdir. Nadiren geldiğini belirten kadın oranı \%7,4 iken erkeklerden bu cevabı veren olmamıştır. Erkeklerin alana daha sık gelme eğilimi sergilediği ortaya çıkmıştır. Yapılan istatistiki analizler önem düzeyi ortaya koymuş, cinsiyet rollerinin alana gelme sıklığına yansıdığını göstermiştir $\left(x^{2}=17,567,5 \mathrm{df}, \mathrm{p}<0.05\right)$

Çizelge 3. Anket Yapılan Kullanıcıların Sosyo-Demografik Verilerinin Dağııımı

\begin{tabular}{|l|l|l|}
\hline Sosyo-Demografik veriler & Kişi Sayısı; N=51 & Oran \% \\
\hline Cinsiyet & & \\
\hline Kadın & 27 & 52,9 \\
Erkek & 24 & 47,1 \\
\hline Yaş & & \\
\hline $18-30$ & 14 & 27,5 \\
$31-40$ & 5 & 9,8 \\
$41-50$ & 9 & 17,6 \\
$51-60$ & 10 & 19,6 \\
$60-$ & 13 & 25,5 \\
\hline Eğitim & & \\
\hline Okur-yazar & 4 & 7,8 \\
İlkokul & 15 & 29,4 \\
Ortaokul & 2 & 3,9 \\
Lise & 11 & 21,6 \\
Üniversite & 19 & 37,3 \\
Lisansüstü & - & - \\
\hline Meslek & & \\
\hline Öğrenci & 9 & 17,6 \\
Emekli & 12 & 23,5 \\
Ev Hanımı & 12 & 23,5 \\
Çalışan & 4 & 7,8 \\
Serbest Meslek & 14 & 27,6 \\
\hline
\end{tabular}

Kullanıcılar alana gelme nedenleri olarak dinlemeye elverişli olması/yorgunluk atmak, yola-merkeze yakın olması/ulaşımı kolay olması, kalabalık/aktif olması, ücretsiz oturma yerleri olması, ortamın güzel olması gibi nedenleri belirtmişlerdir. Tercih nedenleri cinsiyetler açısından kıyaslandığında benzer dağılımlar gözlemlenmiş, istatistiki olarak önemli bir farklılık saptanmamıştır. 
Ankette katılımcılara özgürlük, güvenlik, rahatlık ve karşı cinsin varlığı açısından mekanı nasıl deneyimlediklerini tutum skalaları da sorulmuştur. Kullanıcıların her özellik için belirttiği değerler kadın ve erkek olarak iki ortalamay/a dönüştürülüp karşılaştırmalar yapılmıştır.

Çizelge 4. Kadın ve Erkek Kullanıcıların Alana Gelme Sıklıkları

\begin{tabular}{|l|l|l|l|l|l|l|l|l|}
\hline \multirow{2}{*}{} & & \multicolumn{7}{|c|}{ Alanı ziyaret etme sıklıkları } \\
\cline { 3 - 10 } & Her gün & $\begin{array}{c}\text { Haftada } \\
\text { birkaç } \\
\text { kez }\end{array}$ & $\begin{array}{c}\text { Haftada } \\
\text { bir }\end{array}$ & $\begin{array}{c}\text { Ayda } \\
\text { birkaç } \\
\text { kez }\end{array}$ & Ayda bir & Nadiren & Toplam \\
\hline \multirow{2}{*}{ Kadın } & Sayı & 0 & 12 & 8 & 4 & 1 & 2 & 27 \\
\cline { 2 - 10 } & $\%$ & $0,0 \%$ & $44,4 \%$ & $29,6 \%$ & $14,8 \%$ & $3,7 \%$ & $7,4 \%$ & $100,0 \%$ \\
\hline \multirow{2}{*}{ Erkek } & Sayı & 7 & 5 & 8 & 0 & 4 & 0 & 24 \\
\cline { 2 - 10 } & $\%$ & $29,2 \%$ & $20,8 \%$ & $33,3 \%$ & $0,0 \%$ & $16,7 \%$ & $0,0 \%$ & $100,0 \%$ \\
\hline \multirow{2}{*}{ Toplam } & Sayı & 7 & 17 & 16 & 4 & 5 & 2 & 51 \\
\cline { 2 - 10 } & $\%$ & $13,7 \%$ & $33,3 \%$ & $31,4 \%$ & $7,8 \%$ & $9,8 \%$ & $3,9 \%$ & $100,0 \%$ \\
\hline
\end{tabular}

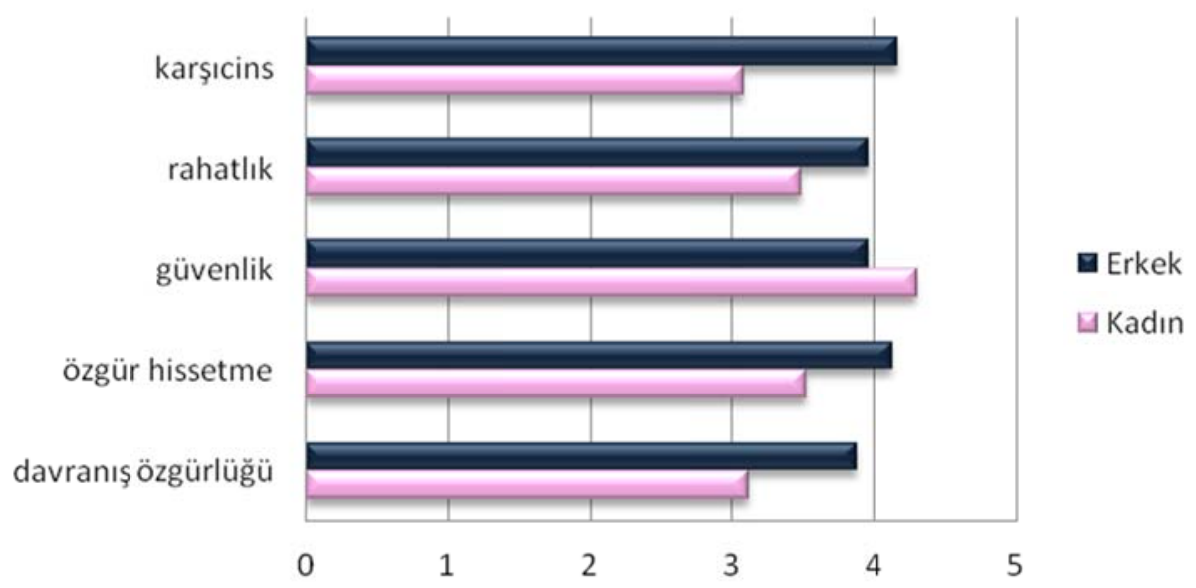

Şekil 3. Kadın ve Erkeklerin Mekansal Deneyimlerine İlişkin Ortalamaların Grafiksel Karşılaştırılması

Analizler kadınların güvenlik dışında tüm değerler bakımından erkeklerden daha düşük ortalamalar ortaya koyduğunu göstermiştir (Şekil 3). Ortaya çıkan bu farklılıkların istatistiki önem düzeyinin saptanması amacıyla T-testi yürütülmüştür; bunun sonucunda davranış özgürlüğü $(t=-2,475,49 \mathrm{df}, p<0,05)$, kendini özgür hissetme $(t=-$ $2,111,49 \mathrm{df}, p<0,05)$, ve karşı cinsten rahatsız olmama $(t=-2,989,49 \mathrm{df}, \mathrm{p}<0,01)$ arasındaki farkın cinsiyet rollerinin etkisini güçlü şekilde yansıttığı saptanmıştır. Güvenlik açısından kadınların alanı erkeklerden daha güvenli bulmasının nedeni benzer araştırmaların bulguları ile açıklanabilir. Kadınların mekânsal özelliklerin yardım istemeyi ya da kaçmayı kolaylaştıran alanları daha güvenli bulduğu; yani yoğun kullanımlı, başkalarının görsel, işitsel ve hareketsel erişim alanında olan ya da merkezi konumda olup hareketsel olarak kaçmanın kolay olduğu yerleri güvenli algıladığı belirtilmiştir. Kadınların açık mekânlarda saldırıya uğrama korkusuna karşılık aldıkları önlemler arasında sayılan bu durum yine kadınların erkeklerden daha zayıf olduklarını, kendilerini savunmak için yardıma ihtiyacı olduğunu kabul eden cinsiyet rollerinin yansımasıdır. Kadınların erkekler kadar özgür hissetmemeleri ve karşı cinsin varlığından erkeklere göre daha az rahatsız olmamalarına karşın rahatlık duygusu bakımından istatistiki olarak anlamlı bir düzey çıkmamasının nedeni kadın kullanıcıların rahatlık kavramını fiziksel olarak algılayıp, özellikle banklarda daha konforlu oturmalarına yönelik bir değerlendirme yapmış olmaları olabilir. 


\section{TARTIŞMA}

Çalışmada elde edilen bulgular Türk kadının kamusal açık mekânlardaki olumsuz durumunu ortaya koyan önceki çalışmaları desteklemiştir. Kadınların yaşamakta olduğu eşitsizlik durumu kamusal açık mekânlara erişimi ve kullanımı için de geçerlidir. Kadın ve erkek kullanıcı sayısında gözlemlenen farklılıklar daha önce başka çalışmaların da ortaya koyduğu eşitsizlik durumunu yansıtır (Bayazitoğu ve Ayyıldız Potur, 2013, s. 545; İnce Güney, 2014, s. 357; Üstün, 2009, s. 386;). Gözlem çalışmasıyla ortaya koyulan bir başka farklılık da kadınlar ve erkeklerin alan içindeki konumlarıdır. Alanda bulunan ve dışarıya açılımı olan çay ocağı (Şekil 4) kadın kullanıcıların da kullandığı bir yerdir, ancak kullanıcı oranları bu konumların erkekler tarafından cinsiyetlendirilmiş mekânlar olduğunu ortaya koymuştur. Doğanay $(2016$, s. 19) çay ocağını erkekliğin üretildiği bir yer olarak değerlendirmekte; erkekliğin oluştuğu mekânları kadının dışlandığı ya da konuk olarak kabul edildikleri yerler olarak tanımlamaktadır. Yine de kadın kullanıcıların çoğunluğunun, ağırlıklı olarak başkalarıyla bir arada olsa da, çay ocağının oturma yerlerinde gözlemlenmesi kadınların bu mekânlardan dışlanma durumunu ortadan kaldırmaya başladığının göstergesi olabilir. Çay ocaklarının kadınların açık mekân kullanımına etkisini daha iyi anlayabilmek için çay ocaklarının olduğu ve olmadığı başka alanlarla bir arada değerlendirmeler yapmak daha sağlıklı sonuçlar ortaya koyacaktır. Kadın kullanıcıların erkek kullanıcıları oran olarak geçtiği tek konum banklardır; kadın kullanıcıların konfor beklentisini yansıtan bu durumun benzeri daha önceki çalışmalarda da tespit edilmiştir (Mumcu,2009, s. 161). Bu sonuçtan yola çıkılarak kadın kullanıcıların ıçekilmek istediği alanların donatı tasarımında kadınların fiziksel konfor beklentilerinin göz önünde tutulmasının iyi sonuçlar ortaya koyabileceği söylenebilir. Kadınların alana ağılıklı olarak başkalarıyla gelmesi benzer bulguları destekler (Bayazitoğu ve Ayyıldız Potur, 2013, s. 545; Demirbaş 2012, s. 86). Açık kamusal alanlarda yalnız kalmama eğilimi başkalarıyla beraber gezmek, silah ya da cep telefonu taşımak, savunma sporları öğrenmek gibi “önlem strateji”leri arasında tanımlanmıştır (Starkweather, 2007, s. 357).
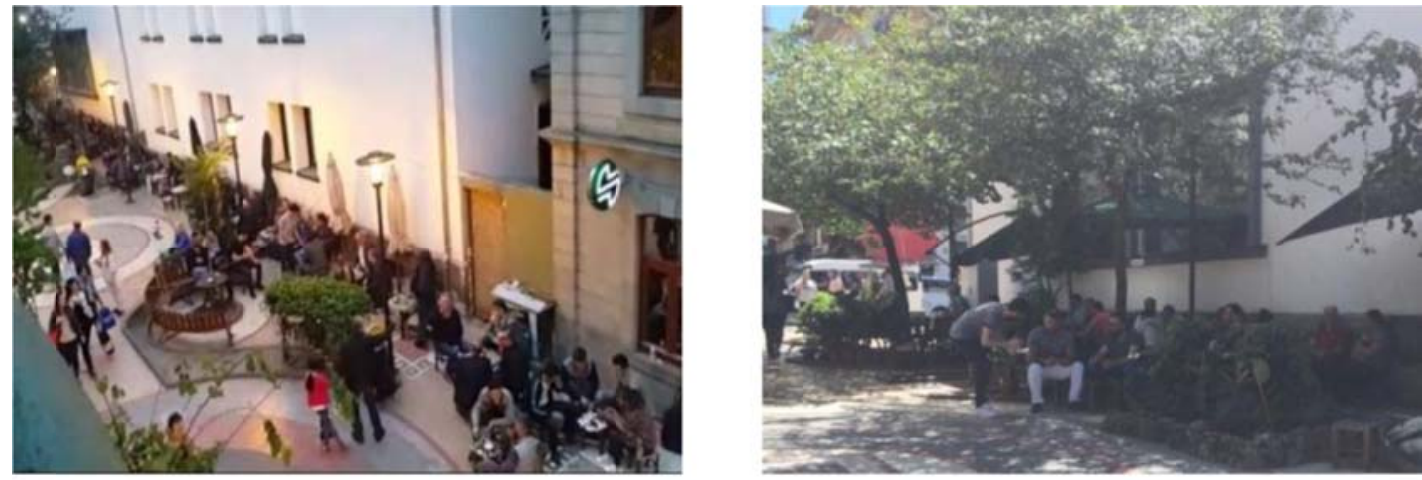

Şekil 4. Alan içinde çay ocağının mekânsal yayılımı ve kullanıcılar (Fot. Sema Mumcu)

Kadın ve erkek kullanıcıların sergiledikleri davranışlarda cinsiyet rollerinin baskısıyla farklıııklar olması, kadınların erkekler kadar özgür olamaması nedeniyle erkekler kadar çeşitli kullanım sergilemeyecekleri beklenilmiş ancak bu sonuç saptanamamıştır. Çeşitlilik olarak kadınlar ve erkeklerin birbirlerine yakın oranlar sergilediği, kadınların 16 etkinlik türü, erkeklerin ise 15 etkinlik türü gerçekleştirdiği gözlemllenmiştir. Kentin merkezinde yer alan, kent hayatının kalbinin attığı merkezi konumlardan biri olan çalışma alanının hava koşullarından bağımsız sürekli canlı, hareketli ve yoğun bir alan olması nedeniyle kadınları daha güvenli ve rahat hissetmeye teşvik ettiği, bunun da davranışsal içeriğe yansıdığı düşünülmektedir. Cinsiyet rollerinin "sergilenmeyen" etkinliklerle daha iyi yansıtıldığı düşünülmektedir; kadınların erkeklere has kabul edilen 
tespih çekmek ya da şans oyunları oynamak gibi davranışları sergilememesi, erkeklerin ise çocuk bakımı, öz çekim (fotoğraf çekimi) gibi daha çok kadınlarla ilişkilendirilen etkinlikleri sergilememiş olmaları gibi.

Yapılan anket çalışması da gözlemde saptanan bazı durumları ve daha önceki araştırmaları desteklemiştir. Buna ilişkin en çarpıcı durum alana gelme sıklıklarıdır. Erkeklerin kadınlara oranla daha sık gelme eğilimi sergilemesi kadınların ev, erkeklerin ise kentsel mekânlarla ilişkilendirilmesi ikilemini yansıtır. Ayrıca kadınların ekonomik olarak daha kısıtlı bütçeye sahip olmaları, ev ve çocuk bakımıyla ilgili sorumluluklarının kendilerine ayıracakları zamanı azaltması da kadınların açık mekânlara erişimini kısıtlandırmaktadır (Akın ve Demirel, 2003, s. 73; Bayazitoğu ve Ayyıldız Potur, 2013, s. 545; Day, 2000, s. 107; Ereş, 2006, s. 47-49; Kansız ve Akın Acuner, 2009, s. 86; KSGM, 2008b, s. 35,44; Üstün, 2009, s. 387; Yılmaz, 2006, s. 100). Anketle ortaya koyulan kadınların kendini erkekler kadar özgür hissetmemesi, karşı cinsten rahatsızlık duymama konusunda erkeklerden daha düşük değerler ortaya koymaları cinsiyet rollerinin oluşturduğu baskıyı yansıtır. İstatistiki olarak anlam düzeyine sahip olmasa da kadınların alanı erkeklerden daha güvenli bulması beklenmeyen bir sonuç gibi dursa da aslında konumun özellikleriyle örtüşmektedir. Bu durum konumun tercih nedenlerinde sıklıkla belirtilen merkezi konumda olması, ayakaltı olması, ana yola yakın olması, kalabalık-aktif olması vb. gibi özelliklerle ilişkilidir. Kadınların başkalarından yardım isteyebilecekleri konumları açık mekânlardaki güvenlik stratejilerinin bir parçası olarak gördüğü başka araştırmalar tarafından da belirtilmiştir (Mehta, 1999, s. 77; Mumcu, 2007, s. 1013).

\section{SONUÇ}

Bu çalışma özellikle sosyal disiplinler içinde yaygın bir çalışma alanı olan kadın-erkek eşitsizliği sorununa çevresel tasarım ve özellikle peyzaj mimarlığı bağlamında odaklanmakta ve kentsel açık mekânların tasarımına ilişkin çalışmalarda göz ardı edilen bu konuyu irdelemektedir. Kamusal açık mekânların kullanımının kadının sosyal statüsünü analiz etmek, anlamak ve iyileştirmek üzere hangi önlemlerin alınacağını belirlemekte iyi bir gösterge olduğu bu çalışmanın yazarları tarafından kabul edilmiştir. Gerek gözlemlerde ortaya koyulan kadın-erkek kullanıcı oranlarındaki farklılıklar, gerekse kadın-erkek kullanıcıların alana kimlerle geldiğindeki farklılıklar kamusal açık mekânlardaki sosyal hayatta kadının olumsuz statüsünü yansıtmaktadır. Mekânın kadın ve erkek kullanıcılar tarafından nasıl deneyimlendiğini saptamaya yönelik anket bulguları da eşitsizliği yansıtır. Kadınların kamusal açık mekânlarda erkekler kadar özgür hissetmemeleri, karşı cinsten daha az rahatsız olmamaları bu duruma örnek verilebilir. Anketle ortaya koyulan bir başka olumsuzluk da kent merkezine gelme sıklıklarındaki farklılıktır.

Bu bulgular karşısında kentsel açık mekânların tasarımıyla yükümlü peyzaj mimarlarına düşen sorumluluklar nelerdir? Elbette kullanıcıları alana çekme bakımından daha demokratik, kullanıcı çeşitliliğini destekleyen alanlar yaşanılır, canlı kentsel mekânların öncelikli özellikleridir. Kadın kullanıcıların varlığı ise kentsel açık mekânların bunu ne kadar başardığının göstergesidir. Kadın kullanıcıların kendini güvende hissetmelerini sağlayacak görsel, işitsel, hareketsel geçirgenliğin yüksek olduğu; hareketliğin, aktivitenin yoğun olduğu yerlerde konumlandırılmış, fiziksel ve mikro iklimsel koşulların konforlu ortamlar sağladığı alanlar kadın kullanıcılar açısından daha avantajı olacaktır. Ayrıca mekân bileşen ve öğelerinin destekleyeceği etkinliklerin içeriği de kadın kullanıcılara yönelik seçenekler sunmalıdır (kermesler, el sanatlarına yönelik pazarlar, sokak gösterileri vb. gibi). 
$\mathrm{Bu}$ çalışmada tek bir alana odaklanılması çalışmanın önemli bir kısıtılığıdır. Özellikle çay ocaklarının getirdiği erkek yoğunluğunun kadınların mekânı kullanması ve deneyimlemesini nasıl etkilediğinin daha iyi anlaşılabilmesi için bu özelliği sergileyen ve sergilemeyen başka alanlarla kıyaslamalar yapılabilir. Anket yapılan denek sayısı ve gözlem süresinin artırılması da gelecekteki araştırmaların güvenilirlik düzeyini yükseltecektir. Yine konforun kadınlar için önemi göz önünde bulundurulursa mekân bileşen ve öğeleri bakımından farklı özellikler sergileyen; farklı donatılar sağlayan mekânlarla kıyaslanmaların yapılması kadınlara yönelik olumlu çevresel özelliklerin daha iyi anlaşıımasını sağlayabilir. Gelecekte yapılacak çalışmalar bu farklııkları bir arada ele alacak şekilde daha çok çalışma alanında yürütülebilir.

\section{KAYNAKLAR}

Akın, Ayşe ve Demirel, Simge, "Toplumsal Cinsiyet Kavramı ve Sağlığa Etkileri” C. Ü. Tıp Fakültesi Dergisi, S:25 (4) 2003, ss. 73-82.

Ardener, Shirley, "The Partition of Space" (ed.) J. Rendell, Gender, Space, and Architecture: Interdisciplinary Introduction, Routledge, London 1999, ss. 112-118.

Bayazitoğlu, Ümit Ceren ve Ayyıldız Potur, Ayla, "Yaşanabilir Kentler Temasını Toplumsal Cinsiyet Bağlamında Yorumlamak: Farklı Kamusal Mekanlarda Karşılaştırmalı Bir Alan Çalışması", 25th International Building \& Life Congress, Liveable Cities, 28 - 30 March 2013, Bursa 2013, ss.541-547.

Blöbaum, Anke ve Hunecke, Marcel, "Perceived danger in urban public space; the impacts of physical features and personal factors", Environment and Behavior, S: 37 (4) 2005, ss. 465-486.

BMOP (Birleşmiş Milletler Kadınların ve Kız Çocuklarının İnsan Haklarının Korunması ve Geliştirilmesi Ortak Programı) Bülteni, Daha lyi Bir Gelecek İçin Kadın Dostu Kentler, S:4 2006.

BMOP (Birleşmiş Milletler Kadınların ve Kız Çocuklarının İnsan Haklarının Korunması ve Geliştirilmesi Ortak Programı), Kadın Dostu Kentler,. Damla Matbaacılık Ltd. Ankara 2010.

Buckingham-Hatfield, Susan, Gender and Environment. Routledge, USA 2000.

Burgess, Jacquelin, 'But is it worth taking the risk?' How women negotiate access to urban woodland: a case study", (ed.) R. Ainley, Space Files: Exploring Bodies, Space and Gender, Routledge, London 1998, ss. 115-130.

Çınar, Alev, Modernity, Islam, and Secularism in Turkey: Bodies, Places, and Time, University of Minnesota Press 2005.

Day, Kristen, "The Ethic of Care and Women's Experiences of Public Space", Journal of Environmental Psychology, S: 20 2000, ss. 103-124.

Day, Kristen, "Constructing Masculinity and Women's Fear in Public Space in Irvine, California", Gender, Place \& Culture: A Journal of Feminist Geography, S: 8 (2) 2001, ss. $109-127$.

Demir, Ümran, "Kadının Toplumsal Statüsü”, Sağlık ve Toplum, S:2 1999, ss. 12-16. 
Demirbaş, Gökben, Kadınların Mekan Algısı ve Mekanı Kullanma Biçimleri, Trakya Üniversitesi Sosyal Bilimler Enstitüsü, (Yayımlanmamış Yüksek Lisans Tezi), Edirne 2012.

Ereş, Figen, "Türkiye'de Kadinin Statüsü ve Yansimalari”, Gazi Üniversitesi Endüstriyel Sanatlar Eğitim Fakültesi Dergisi, S:19 2006, ss. 40-52.

Fisher, Bonnie S. ve Nasar, Jack L., "Fear of Crime in Relation to Three Exterior Sites Features; Prospect, Refuge, and Escape", Environment and Behavior, S:24 (1) 1992, ss.35-65.

Doğanay, Gülmelek, "Unutma ve anımsama arasında geçmişin eril inşası: Çaykara'da kadın olmak ve geçmişin reddi”, Fe Dergi, S:8 (1) 2016, ss.15-33.

Günindi Ersöz, Ayşegül, "Özel Alan/Kamusal Alan Dikotomisi: Kadınlığın "Doğası" ve Kamusal Alandan Dışlanmışlığı", Sosyoloji Araştırmaları Dergisi, S:18 2015, ss. 80-102

Gökarıksel, Banu ve Secor, Anna, "Between Fashion and Tesettür: Marketing and Consuming Women's Islamic Dress", Journal of Middle East Women's Studies, S:6(3) 2010, ss.118-148.

İnce Güney, Yasemin, "Gender and urban space: An examination of a small Anatolian city", ITU A|Z, S: 11 (2) 2014, ss.153-172.

Kansız, Nuray ve Akın Acuner, Şebnem, Kadınların Kentsel Hizmetlerden Yararlanma Düzeyleri, Sorunlar ve Çözüm Önerileri, Milli Prodüktivite Merkezi Yayınları, Ankara 2009.

Koskela, Hille, “'Gendered Exclusions': women's fear of violence and changing relations to space", Geografiska Annaler, S:81 B (2) 1999, ss. 111-124.

Krenichyn, Kira, "Women and physical activity in an urban park: Enrichment and support through an ethic of care" Journal of Environmental Psychology, S:24 2004, ss. $117-130$.

KSGM, (Kadının Statüsü Genel Müdürlüğü), T.C. Başbakanlık, Kadının Statüsü Genel Müdürlüğü. Kadının Statüsü ve Sağlığıyla Illgili Gerçekler. Afşaroğlu Matbaası, Ankara 2008a.

KSGM, (Kadının Statüsü Genel Müdürlüğü), T.C. Başbakanlık, Kadının Statüsü Genel Müdürlüğü, Toplumsal Cinsiyet Eşitliği Ulusal Eylem Planı 2008-2013, Fersa Ofset, Ankara 2008b.

KSGM, (Kadının Statüsü Genel Müdürlüğü), T.C. Başbakanlık, Kadının Statüsü Genel Müdürlüğü, Türkiye'de Kadının Durumu, Ankara 2012.

(http://www.kadininstatusu.gov.tr/upload/mce/2012/trde kadinin durumu 2012 nisan.p df), (28.05.2015)

Massey, Doreen, "Space, Place and Gender", (ed.) J. Rendell, Gender, Space, Architecture: Interdisciplinary Introduction, Routledge, London 1999, ss.128-133.

Mehta, Anna, "Embodied Discourse: On gender and fear of violence", Gender, Place \& Culture: A Journal of Feminist Geography, S:6(1) 1999, ss. 67-84. 
Mumcu, Sema, Açık Mekanlarda Davranış Konumları: Oturma Davranışının Değişiminin Incelenmesi, Karadeniz Teknik Üniversitesi, (Yayımlanmamış Doktora Tezi), Trabzon 2009.

Mumcu, Sema; Yılmaz, Serap ve Özbilen, Ali, "The Factors Influencing the Feeling of Safety in Urban Open Spaces" LINENARCH $3^{\text {rd }}$ International Congress, Contextualizm in Architecture, July 5-7, 2007, Trabzon, Turkey, C.3, ss. 1007-1015.

Reid, Bryonie, "Rearranging the ground': public and private space in Belfast, Northern Ireland." Gender, Place \& Culture: A Journal of Feminist Geography, S:15 (5) 2008, ss. 489-503.

Rendell, Jane, "Introduction: 'Gender, Space”, (ed.) J. Rendell, Gender, Space, Architecture: Interdisciplinary Introduction, Routledge, London 1999, ss. 101-108.

Sewell, Jessica, "Gender, Imagination, and Experience in the Early-Twentieth-Century American Downtown." (ed.) C. Wilson, Everyday America: Cultural Landscape Studies after J. B. Jackson, University of California Press, Ewing 2003, ss. 237-254.

Starkweather, Sarah, "Gender, Perceptions of Safety and Strategic Responses among Ohio University Students" Gender, Place \& Culture: A Journal of Feminist Geography, S:14(3) 2007, ss. 355-370.

Tiftik, Cemile ve Turan, İlker, "Women, Social Housing and Urban Spaces: Places to dwell and places where women are being attacked on their way home", ITU A|Z, S:12 (1) 2015 , ss.243-255.

Üstün, İlknur, “Trabzon'un Misafirleri”, (ed.) Güven Bakırezer, ve Yücel Demirer, Trabzon'u Anlamak, İletişim Yayınları, İstanbul 2009, ss. 361-402.

Wesely, Jennifer K. ve Gaarder, Emily, "The Gendered "Nature" of the Urban Outdoors; Women Negotiating Fear of Violence", Gender \& Society, S:18 (5) 2004, ss. 645-663.

Yılmaz, Zeynep, Kamusal Mekanların Gender Sistematik Yaklaşım Açısından Değerlendirilmesi, Karadeniz Teknik Üniversitesi, (Yayımlanmamış Yüksek Lisans Tezi), Trabzon 2006. 